\title{
Silent Partners: The Role of Unpaid Market Labor in Families
}

Lisa Philipps

Osgoode Hall Law School of York University, Iphilipps@osgoode.yorku.ca

\section{Source Publication:}

Feminist Economics. Volume 14, Number 2 (2008), p. 37-57.

Follow this and additional works at: https://digitalcommons.osgoode.yorku.ca/scholarly_works

Part of the Labor and Employment Law Commons, Law and Economics Commons, and the Law and Gender Commons

(c) $(1) \Theta(9$

This work is licensed under a Creative Commons Attribution-Noncommercial-No Derivative Works 4.0 License.

\section{Recommended Citation}

Philipps, Lisa. "Silent Partners: The Role of Unpaid Market Labor in Families." Feminist Economics 14.2 (2008): 37-57.

This Article is brought to you for free and open access by the Faculty Scholarship at Osgoode Digital Commons. It has been accepted for inclusion in Articles \& Book Chapters by an authorized administrator of Osgoode Digital Commons. 


\title{
SILENT PARTNERS: THE ROLE OF UNPAID \\ MARKET LABOR IN FAMILIES
}

\author{
Lisa Philipps
}

\begin{abstract}
The term ' 'unpaid market labor' ' refers to the direct contributions of unpaid family members to market work that officially belongs to another member of the household. Thus one individual may be construed legally as an owner or entrepreneur, but relatives may help out informally with business operations. Likewise, in corporate or public-service settings, certain employees rely on the unpaid help of an executive spouse or political wife. This paper argues that unpaid market labor is conceptually distinct from both paid work and unpaid domestic labor. Legal cases from Canada are used to illustrate the policy implications of this insight and how dichotomous thinking about the market and the family obscures this kind of work. The article discusses insights and challenges for feminist political economy in theorizing unpaid market labor.
\end{abstract}

KEYWORDS

Gender inequality, taxation, unpaid work

\section{INTRODUCTION}

This paper discusses a form of unpaid work that has largely been invisible in studies of both paid and unpaid labor in highly industrialized countries such as Canada, the United States, the United Kingdom, and Australia: the involvement of family members in bread-winning activities that are the official responsibility of only one person in the household. To offer a few classic examples, this is the work of the unpaid relative who helps out in the back room of the family business, the executive spouse who organizes 
corporate functions, the political wife who campaigns with and informally advises her husband, or the farm wife who shares in operations and management but lacks formal status as a co-owner or employee. The term ' 'unpaid market labor', is used here to describe these and other contributions to the paid work of individuals who are construed legally and socially as individual employees, public officials, or entrepreneurs. It reflects this paper' s overarching claim that unpaid market labor is distinct from both unpaid domestic labor and paid market work in ways that matter to feminist legal and economic theory.

Unpaid market labor does not map easily onto the familiar dichotomies of market versus family and paid versus unpaid work that frame most feminist as well as conventional analyses of Western women' s labor. Though provided in a familial context, it goes beyond the childcare, housekeeping, and other tasks generally understood as domestic. It includes tasks that are harder to distinguish from the work of the remunerated family member, are often done in the same physical location, and contribute more visibly to market earnings. Yet, unpaid market labor is not directly remunerated and does not carry the legal rights or obligations of employment or selfemployment.

This paper seeks to demonstrate both the public-policy relevance of unpaid market labor and its significance for feminist political economic 
theory. It draws upon tax judgments from Canada to illustrate how this form of work often disappears into a conceptual gap between market and family labor, obscuring its many implications for economic gender equality. Yet the sociological studies reviewed here show that unpaid market labor is essential to family livelihoods in highly industrialized countries, in a wide variety of economic sectors and class settings. These findings raise new questions for feminist theorizing about labor markets and the care economy. Greater attention to unpaid market labor may show that markets and households are not just interdependent, but fundamentally inseparable in the process of social reproduction. In order to address these questions, more detailed empirical knowledge is required about the nature and extent of unpaid market labor being undertaken by different population groups across industries and countries.

\section{POLICY IMPLICATIONS OF UNPAID MARKET LABOR: THE EXAMPLE OF TAXATION LAW}

This research began through my teaching of Canadian taxation law when I encountered cases in which individual taxpayers argued that some portion of their income should be attributed to an unpaid family member who 
actively assisted with the taxpayer' s business or employment duties. I review a small selection of these cases to illustrate how unpaid market labor tends to fall into a conceptual blind spot between waged work and domestic life in Canada and the difficulties this poses for adjudicators and policy makers. Similar issues are likely to arise under the income tax laws of other countries and in a range of other public policy fields.

Unpaid work is officially outside the scope of the Canadian income tax, which like other income tax systems around the world, is designed to catch only monetized forms of income and expense. Indeed, feminist legal scholars have argued that one of the main sources of gender bias in tax policy is its tendency to focus exclusively on market income and to disregard the economic benefits flowing from household production (Nancy C. Staudt 1996; Lisa Philipps 2002). Unpaid work is not taxed directly but can still generate tax issues because of its close relationship to the income-earning activities of another individual or firm. The technical issues vary among cases and countries, but the common theme is that a business owner or employee seeks to avoid tax on some portion of their income, which they argue is properly allocated to a family member who provided informal assistance with the work. Thus, the taxpayers in these cases seek to characterize the family member' s work as a form of productive and commercially valuable labor, even though it was not compensated in 
money. The revenue authorities, on the other hand, seek to characterize the unpaid work as a personal, familial activity, or even a form of leisure, unrelated to the earning of income. Judges must choose between these dichotomous characterizations for purposes of determining tax liability. The decisions fall into two groups, described here as the ' "executive spouse' ' cases and the ' 'family business' ' cases.

The executive spouse

These cases deal with employees whose spouses accompany them on business trips at the company' $\mathrm{s}$ expense. The legal issue in Canada is whether the employer' s payment of a spouse' $\mathrm{s}$ travel costs constitutes a taxable benefit to the employee. This in turn depends on whether the spouse' s presence was primarily for the employee' s personal benefit (in which case it is taxable), or primarily for the benefit of the employer (in which case it is non-taxable). The cases discussed below were decided between 1966 and 1996 and most involve management or executive level employees. With one exception, they all deal with male employees accompanied by their wives. In all the cases involving male employees, the Courts referred to evidence about the tasks done by the wives. The most pervasive theme is the wives' role in mediating relationships. They 
facilitated interactions with business associates, suppliers, or customers and otherwise nurtured the social framework for business activity. The wives attended training seminars alongside their husbands; hosted and attended receptions, dinners, and other social events; and were often responsible for shepherding and monitoring the wives of lower-level employees attending the convention or meeting. While the fact patterns are often similar in these cases, the judgments are divided between those that characterize the spouse' s accompaniment as mere personal companionship (giving rise to a taxable benefit) and those that determine the spouse to be contributing to the business aims of the trip.

Taxpayers invariably argued that spouses were along to serve the employers' business interests. For example, in Shambrook v. Minister of National Revenue, the president of a metalwares company argued:

It was necessary for [his wife] ... to accompany him to the President' $\mathrm{s}$ Reception and Buffet Supper, to take part in other social activities attended by delegates and their wives during the course of the convention, to meet and fraternize with the wives of others attending the convention, and thus promote a general atmosphere of friendship and goodwill with both competitors and customers (or potential customers). (Tax Appeal Board 1966: 21). 
The Tax Appeal Board rejected this portrayal of the wife' s activities and held that the company had conferred a taxable benefit on the husband by paying her travel expenses:

[T]he benefit received by Mr. Shambrook... might properly be said to have been of a personal nature in that he had been able to enjoy the companionship of his wife at the convention as well as the social advantages of attending the various functions as her escort rather than alone. (Tax Appeal Board 1966: 23)

This reasoning was echoed in Paton v. Minister of National Revenue (Tax Appeal Board 1968), when a senior executive of a bank argued that there was a business purpose for his wife' $\mathrm{s}$ attendance at regional meetings, especially so that she could evaluate the wives of local branch managers. $\mathrm{He}$ stated:

[E]xperience has shown that in the operation of a branch the manager' $s$ wife can play an important role in the business development and servicing fields. Because of this, it is important that the wife be aware of the bank' $\mathrm{s}$ objectives and that the bank be in a position to assess the wife' s contribution. In making this evaluation... the executive' s wife can be of considerable assistance. (Tax Appeal Board 1968: 198)

In rejecting the taxpayer' $\mathrm{s}$ argument and upholding the government' $\mathrm{s}$ 
assessment of a taxable benefit the Board questioned the skills that Mrs. Paton could bring to this role:

There is no evidence that Mrs. Paton spent any time in the head office of the bank to learn the intricacies of banking practice; neither was there any evidence that she had any special fitness or training to enable her to pass judgment on the abilities and qualities of the various people she would meet fleetingly at the social function... (Tax Appeal Board 1968: 201).

The courts in Shambrook and Paton therefore saw the wives' activities as fundamentally personal and not part of the networking, advertising, customer relations, and human resources management that are essential to the generation of business profits.

A valid policy concern of both revenue authorities and Courts in these cases is to prevent tax avoidance by high-income earners who seek merely to shift income to a spouse in a lower tax bracket, as suggested by the following passage:

Mr. Paton' s tax return shows him to be in receipt of a highly substantial salary as one would expect of a senior executive in one of the chartered banks in Canada. Nevertheless he seeks to be relieved of taxation in respect of the ... expenses incurred on behalf of his wife when she 
accompanied him to Western Canada. (Tax Appeal Board 1968: 201).

From this perspective, the cases appear to pit the interests of class (or vertical) equity against the recognition of women's unpaid labor. This framing of the issue places class and gender equality interests in conflict, not unlike Symes vs. The Queen, in which a Canadian lawyer sought unsuccessfully to deduct her nanny' s salary as an expense of carrying on business (Supreme Court of Canada 1994; Audrey Macklin 1992). Notably, however, the courts in the Paton and Shambrook cases did not challenge the business nature of social hosting activities for the executives themselves. They had no difficulty recognizing the employees' own attendance at receptions and dinners as part of the income-earning process. The fact that these events also met the executives' personal needs for food, drink, and entertainment raised no problem of class inequity for the courts.

Indeed other cases from the same time period (late 1960s/early 1970s) in Canada reached the opposite conclusion by allowing travel expenses for an executive spouse to be reimbursed without tax. A good example is Hale $v$. Canada, where the manager of an insurance company brought his wife to a conference of insurance brokers held at a resort in Phoenix, Arizona at the company' s expense (Exchequer Court 1969). The Court held there was no taxable benefit to Mr. Hale due to his wife' s extensive involvement in conference activities and the fact that her presence was ' 'tantamount to 
being obligatory', within the corporate culture of the insurance company (Exchequer Court 1969: 262). This case provides a fascinating glimpse of the extent to which certain employers have relied upon executive spouses to help run their operations. As the court found,

The company has a strong preference for married men over those who are unmarried. It does not hire an applicant as a salesman ... if his wife does not meet the company standards. The wife is interviewed separately and in person prior to hiring the husband, and ... when [Mr. Hale] engaged a salesman this interview of the applicant' $\mathrm{s}$ wife was done by his wife who reported her assessment of the [applicant' s] wife to him. The company maintains a direct liaison with the wife through all stages of her husband's career. She is sent correspondence and pamphlets giving instructions and guidance on how to help her husband... Canada Life regards the combination of the husband and wife as the selling unit in the business and takes active steps to foster the wife' s participation, but they do not pay her. (Exchequer Court 1969: 261)

The tasks that the court considered as relevant to the business objectives of the conference included the following:

Mrs. Hale assumed the responsibility of looking after wives of the 
salesmen, arranging the assignment of rooms in congenial company, finding their baggage lost in transit, urging their attendance at the business sessions and observing and reporting any absentees to her husband... She attempted to broaden her knowledge of her husband' s business by attending their instructional meetings... She acted as the appellant' $\mathrm{s}$ hostess at informal gatherings arranged by her husband for his colleagues and their wives... In short she acted as a kind of mother superior to the branch salesmen' s wives. (Exchequer Court 1969: 263)

Contrary to the Shambrook and Paton cases discussed above, the court in Hale was satisfied that ' 'this was not a holiday for her at the company' sexpense' ' (Exchequer Court 1969: 264). Likewise in Philp vs. Canada, where the taxpayer managed a grocery store, the court found that wives contributed useful knowledge about the preferences of women customers and also ensured the convention would be ' 'more orderly and businesslike' ' (implying they would discourage wild behavior by the men) (Exchequer Court 1970: 500).

While the images of the corporate spouse in these cases may seem outdated, very similar issues arose in Lowe v. Her Majesty the Queen (Federal Court of Appeal 1996). Mrs. Lowe accompanied her husband, an account executive with an insurance company, on a trip to New Orleans. The trip was an incentive reward for independent brokers who sold the company' $s$ 
products, and the Lowes were responsible for guiding and assisting brokers and their wives and nurturing relationships with them throughout the ' 'four sun-filled days and fun-filled nights', promised in the program (Federal Court of Appeal 1996: 6228 - 9). In holding that Mrs. Lowe' s company-paid travel did not constitute a taxable benefit to Mr. Lowe, the Court acknowledged that times had changed, and spouses probably are not as heavily obliged to attend such functions as they were at the time of Hale (Federal Court of Appeal 1996: 6230). Nonetheless, Mrs. Lowe did attend, and the Court found she spent virtually all her time assisting her husband. This included attending a training session with her husband on ' "how to deal with the brokers, when to discuss business during the four days, where to sit during meals and also to arrange meetings with brokers and senior management' ' (Federal Court of Appeal 1996: 6227). For example, account executives were told to encourage brokers and their wives to sign up for guided tours, and while on the tours, Mrs. Lowe would talk with the other wives while Mr. Lowe discussed business with the brokers. Given their constant involvement with such activities, the Court held that any personal enjoyment was ' 'merely incidental to what was primarily a business trip by both spouses for the purpose of advancing the employer' $\mathrm{s}$ business interests' ' (Federal Court of Appeal 1996: 6230).

The Lowe case suggests that the executive-spouse role is not a mere relic 
of the past. While fewer women may be full-time executive spouses to the exclusion of their own careers, this has not made the role obsolete. Rather, unpaid market labor is more likely being transformed along with other aspects of women' $\mathrm{s}$ work. It may be provided more intermittently as an additional shift of labor by a spouse with a paid job of her own, or it may draw upon skills or status acquired by women through their own careers. Despite such changes, the Lowe case reflects a continued reliance upon women to facilitate the human relationships needed for business success.

An important question is whether women employees have comparable access to the services of an executive spouse, as they seek higher positions in corporate management. One case from 1993 dealt with a woman operations manager who was asked by her employer to join a group traveling to Japan to visit the offices of a key supplier. The court found that the trip ' 'was not merely offered to her... she was politely, but I gathered firmly, requested to go' ' to avoid the embarrassment of spaces being left open (Tax Court of Canada 1993: para.7). The employer also requested that she take her husband. She agreed with some reluctance in light of the cost to her husband' s own work time and possibly vacation time. It is notable that none of the other cases mentioned any concerns about the personal or career costs to wives of accompanying their husbands on business travel. 
Though acknowledging the relatively mandatory nature of the trip, the Court held that the reimbursement of the husband' s expenses was a taxable benefit ' 'since his trip was of no benefit to the company of which I am aware' ' (Tax Court of Canada 1993: para. 15), and since Ms. McMillan ultimately made the choice to include him. Justice Taylor stated: although ' 'rejecting that condition might have meant she did not go on the trip, I regard it as a conscious decision to take the opportunity on her part' ' (Tax Court of Canada 1993: para. 16). In contrast to the cases discussed earlier, the judge did not describe the husband' s specific activities but mentioned only that the itinerary included ' 'the usual mix of social events' ' and more direct business activities (Tax Court of Canada 1993: para. 3). There was no recognition that the husband was assisting his wife or her employer to achieve the business objectives of the trip, even though his physical presence was obviously thought to be important to make the right impression on the supplier. As a result, the value of his trip was added to McMillan’ s employment income for tax purposes.

Overall, then, Canadian tax jurisprudence has been conflicted about whether the activities of an executive spouse primarily serve a business or family purpose. While factual distinctions can of course be identified, they are not so obvious as to explain by themselves why the Courts reached opposing conclusions in these cases. The same pattern of seemingly 
irreconcilable decisions repeats itself in the family business cases.

The family business

In these cases, the taxpayer owns a business and attempts to split the profits for income tax purposes with a family member who is taxed at a lower rate. Taxpayers have an incentive to split income with lower earners under any system of progressive rates, though the technical means employed will vary with the economic circumstances and depending on how the tax law is designed. Many jurisdictions have struggled to define when income splitting is inappropriate and to draft effective anti-avoidance rules (Maureen Donnelly, Joanne Magee, and Allister Young 2000; UK Inland Revenue n.d.). A key issue in some cases is whether the family member provided business-related services that justify an allocation of profits or wages. Disputes can then arise over the nature and value of unpaid market labor. The difficulty of knowing when authorities or courts will characterize such work as business or personal activity is illustrated by two cases, Cullen vs. Canada (Tax Court of Canada 1985a) and Wessell vs. Canada (Tax Court Canada 1985b).

In both cases, the taxpayer claimed he was carrying on a business partnership with his wife, who was therefore entitled to report a share of 
profits. The court reached opposite decisions in the two cases despite strikingly similar fact patterns. Both involved small businesses in which the husband initially reported all the income as a sole proprietor and later switched to filing as a partnership on the advice of professional accountants. The evidence established that the businesses were managed and operated jointly by husband and wife. However, there was no written partnership agreement, nor did the wife receive wages or any other formal compensation for her labor. The issue was whether the couple met the legal definition of partnership as a relationship between persons ' 'carrying on a business in common, with a view of profit' ' (Tax Court of Canada 1985a: 412). ${ }^{1}$ As both judges acknowledged, the absence of a written contract is not fatal if the parties' conduct indicates there was an oral or implied partnership agreement (Tax Court of Canada 1985a: 412; Tax Court of Canada 1985b: 208 - 9). Evidence detailing how the couples shared responsibility for their businesses reveals strong parallels between the two cases.

The Wessells operated three separate enterprises: a trailer park, a farm, and a construction business. The court found that Mrs. Wessell contributed to the ' 'physical requirements' ' of all three; she also negotiated contracts and ' was recognized and accepted by the public as an active and authoritative person in the operation' ' (Tax Court of Canada 1985b: 207). 
Justice Taylor commented:

[I]n many aspects of the operations Mrs. Wessell acted and functioned virtually independently of the appellant - her husband - indeed without even consulting him, while at the same time on many other aspects he consulted with her before signing contracts, buying equipment, etc. It could well be said that in matters of finance she was actually in control of the funds. (Tax Court of Canada 1985b: 207)

The couple divided their labor differently in each of their businesses: ' 'With regard to the construction business, the appellant was the major element, and his wife did provide substantial assistance. For the 'trailer park' ... Mrs. Wessell was the major motivator, consulted and aided by Mr. Wessell' ' (Tax Court of Canada 1985b: 209). Based on their conduct, the court held that the Wessells had a valid partnership that was affirmed by their decision to file tax returns as partners, each reporting a share of the profits from each business (Tax Court of Canada 1985b: 209).

As in the Wessell case, the Cullens also had three businesses: an oil distributorship, a farm, and a racehorse operation. With respect to the farm, the judge found that both spouses were ' 'equally involved in all aspects of the operation' ' (Tax Court of Canada 1985a: 410). In addition to a wide range of manual and marketing tasks, ' 'Caroline was fully involved in 
all decisions .... and it was her particular responsibility to maintain the necessary books and records' ' (Tax Court of Canada 1985a: 410). Later she was also heavily involved in the oil agency:

The nature of the business was such that at certain times... Cullen would be required to spend all of his time away from the agency office... As a result Caroline was the person responsible for the day to day management of the agency. This included everything from answering the telephone to the preparing and rendering of accounts to customers. She did all of the banking, kept all the books of account, and in recent years has had the responsibility for the operation of the computer... It was her evidence that ... she customarily worked five days a week from 8:30 in the morning to 5:00 in the afternoon (and often longer during busy seasons). She has never been paid a salary. (Tax Court of Canada 1985a: 411)

Likewise both spouses were involved in all decisions relating to the racehorse operation, and Mrs. Cullen maintained ' 'all of the racing documents, breeding records and the books of account' ' (Tax Court of Canada 1985a: 411).

In this case, however, the court found there was no legal partnership, stressing that most assets as well as loans and advertisements were held in Mr. Cullen' s name alone (though Caroline had an interest in farm land pledged 
as security for a loan and had signing authority on bank accounts) (Tax Court of Canada 1985a: 411, 413). With respect to the oil distributorship, the couple testified that Imperial Oil would not allow Mrs. Cullen to sign the purchase documents as a partner but insisted on dealing with Mr. Cullen alone (Tax Court of Canada 1985a: 411). Justice Sarchuk gave little credence to this testimony, questioning why Mrs. Cullen did not speak to her lawyer or accountant about challenging this policy if partnership status was truly important to her (Tax Court of Canada 1985a: 414). The court concluded that although the couple pooled their assets upon marriage, ' 'this was incidental to the formation of the family unit' ' (Tax Court of Canada 1985a: 414). In contrast to the decision in Wessell, Mrs. Cullen' s contribution of unpaid labor was construed ultimately as a function of the family relationship and not as evidence of a business relationship. The contradictory results in these two cases highlights the law' s ambivalence about the nature of such activities and the awkwardness of placing them solely on one side or the other of the business/personal divide.

As a group, the executive spouse and family business cases from Canada raise difficult questions about how best to ensure equitable treatment of those who provide unpaid market labor. The cases that refused to recognize the business nature of the spouses' activities directly devalued their work. Yet in the others, where the taxpayers won their cases, the effect 
was merely to reduce the male breadwinner' $\mathrm{s}$ tax burden with no guarantee of compensation actually being received by the spouse. In fact, the protaxpayer decisions discouraged the creation of formal partnership or employment contracts with spouses, since the benefits of income splitting can be obtained without doing so. Parallel issues are likely to arise under the tax regimes of other countries such as the US, England, and Australia. However, this policy conundrum cannot be resolved within the narrow conceptual confines of tax law. Rather, it suggests the need to rethink more broadly the role of unpaid relatives in securing family livelihoods. Doing so will have implications not just for tax law but many aspects of public policy, as discussed briefly in the concluding part of this article.

\section{THEORIZING UNPAID MARKET LABOR}

Beyond specific problems of legal policy, the tax cases discussed above raise several larger questions for feminist political and economic theory. First among these is whether unpaid market labor is properly described as ' 'unpaid' ' work. Even if not directly remunerated, might it be paid for indirectly through higher wages or profits to the official market actor that are then shared within the household among those who have contributed to the enterprise? Historical studies of cottage industries in England and 
Canada have found that women and children were involved directly in production, and family wages were set explicitly by reference to the number of household members participating in the work (Ivy Pinchbeck 1969: 121 - 2; Paul Phillips and Erin Phillips 1993: 12 - 14). In contemporary times, it seems likely that having a family member available to help with one' s work could boost the earning capacity of an individual employee or entrepreneur. This may help explain the wage premium enjoyed by married men in certain professional and corporate contexts in highly industrialized countries (Belinda Hewitt, Mark Western, and Janeen Baxter 2005). Certainly, the literature on Northern family business identifies access to a flexible supply of both paid and unpaid labor within the family as a key comparative advantage (Jane Wheelock 1992; Peter Leach, Bruce Ball, and Garry Duncan 2003: 7).

Even if it could be demonstrated empirically that unpaid market labor sometimes translates into a higher cash income for the official breadwinner, the other family member may remain unpaid in the sense of lacking legal title to or decision-making power over that income. Neither equal sharing nor equal control of resources can be assumed within such families (Shelley Phipps and Frances Woolley 2006). The notion that unpaid market labor will be compensated indirectly within the family is vulnerable to the same criticisms that feminists have leveled at the family wage system of 
industrial capitalism: that it both assumes and promotes women' s economic dependence on male breadwinners (Alice Kessler-Harris 2001). Moreover, searching for wage premiums suggests that markets can differentiate among individuals on the basis of who has access to the services of an unpaid family member. If market work is presumed instead to be collective by nature, such that reliance on unpaid market labor is the norm rather than the exception, then wage premiums are unlikely to account for all such work.

A further question is whether unpaid market labor is a mere vestige of the family-wage ideal, of declining relevance in many industrialized countries as women increasingly take on waged work of their own. Even two decades ago, Hillary Callan observed that employers in the UK could no longer ' 'unreflectingly count on a wife' $s$ willingness to provide unpaid and unrecognized services. The growing visibility of symmetrical marriages, female executives and men in the position of 'spouse' has undermined many of the symbolic associations, as well as the concrete expectations' ' of earlier times (1984: 4). As more women gain access to the upper tiers of the labor market in industrialized countries (Sylvia Walby 2000: 165 - 97; Lourdes Beneria 2003: 121 - 4), or enter self-employment in their own right (Karen D. Hughes 1999), how is this likely to affect the provision of unpaid market labor and its distribution among men and women? This question really has two 
aspects: (1) whether women will adjust to such changes by providing less unpaid market labor to family breadwinners, and (2) whether women' s own market opportunities will be affected by their access, or lack thereof, to unpaid market labor provided by other family members. It would be problematic simply to assume that women are relieved of unpaid market labor when they obtain their own paid jobs. Feminist research has demonstrated that while gendered work patterns in the US have shifted to some extent, even employed women still do more childcare and other unpaid household work than men and are more likely to hold poorer jobs on the so-called ' track' (Carmen Sirianni and Cynthia Negrey 2000; Joan Williams 2000). Similarly, women' s changing labor-force participation seems more likely to transform rather than eliminate the provision of unpaid market labor. Those pursuing a masculine career model of exclusive dedication to the job will still face competitive pressures to enlist their wives' assistance in various technical, clerical, social hosting, counseling, charitable, and other statusmainte- nance functions (Sirianni and Negrey 2000: 67; see also Rosabeth Moss Kanter 1977: 106). Recent qualitative studies in Anglo-American countries have reported that women provide such services as a third shift, over and above their domestic responsibilities and their own waged work (Marian Binkley 2002: 33 - 5; Barbara R. Rowe and Gong-Soog Hong 2000: 3), sometimes compromising their own positions in the labor market to 
accommodate a husband' s need for business help (Susan Baines and Jane Wheelock 1998: 588 - 90). Indeed, research by Baines and Wheelock suggests that the flexibilization of labor markets in the late twentieth century is probably increasing the importance of unpaid market labor, as many UK families become ' 're-embedded in the economic institution of the new small business' (1998: 580, 582).

Nor has the role of full-time ' 'corporate wife' ' entirely disappeared in these countries (Anne Kingston 2001; Linda Rhodes 2003). Indeed, as businesses expand globally and certain employees are called upon to travel and relocate frequently, it may become even harder to sustain two careers within one family. Some corporate wives assert their role is becoming more not less intensive, as expectations rise about women' s business knowledge and work becomes more geographically mobile (Betsy Morris 1998). This observation resonates with the case discussed earlier in which Mrs. Cullen assumed responsibility for operating the computer in the later years of the family business.

There is also some evidence that unequal access to unpaid market labor constrains women' s career success. The McMillan case discussed above serves as a concrete example of how women employees may be disadvantaged in this regard. McMillan' s decision to accede to employer pressure to bring her husband on the business trip was made reluctantly, 
with an awareness that it conflicted with his own employment and personal priorities. More broadly, one study of Canadian women business owners found they generally had less access than male entrepreneurs to a flexible supply of unpaid family assistance (Monica Belcourt, Ronald J. Burke, and Hélène Lee-Gosselin 1991: 39). All of these questions call for further empirical research.

Another consideration is how gender may be infused or even superseded by other dimensions of power in shaping the nature and meanings of unpaid market labor in various contexts. This is not to deny the gendered nature of unpaid market labor or its important role in white middle-class life. Both historically and in contemporary times, the availability of a full- time wife dedicated to advancing her husband' $\mathrm{s}$ career has been a critical signifier of bourgeois economic, sexual, and moral status (Callan 1984: 3 4; Leonore Davidoff and Catherine Hall 2002: 279 - 87). Baines and Wheelock found that even in the new wave of micro-businesses, the division of tasks among family members was highly gendered along traditional lines (1998: $587-8)$. A wife' s participation in business travel or other functions often has been made possible by shifting regular household labor to domestic servants, often poorly paid women of color. This analysis could be broadened to consider how and why unpaid market labor is provided in different class settings, among families with different ethnic connections 
and racialized identities, by children, husbands, and extended family, including male relatives (Janet Finch 1983: 1 - 2). For example, some qualitative studies of small businesses in racialized and immigrant communities in highly industrialized countries have found that unpaid family members including children can play a very important role in securing the survival of the business (Kwang Chung Kim and Won Moo Hurh 1988: 154; In-Sook Lim 1997: 4; Margaret Walton-Roberts and Daniel Hiebert 1997: 6 - 8; Spinder Dhaliwal 1998). Industrial homeworkers are another group likely to incorporate family members, including children, into the labor process in order to speed production and attempt to generate a living wage for the household (Eileen Boris 1994: 94 - 111). These studies suggest that more than gender is at play in determining who provides and benefits from unpaid market labor.

Feminist theory must additionally attend to the prescriptive question of how unpaid market labor should ideally be treated, whether by rewarding it as a valuable form of economic contribution or by discouraging it as an inherently oppressive practice. Particularly in the family business context, some argue it enhances women' s agency by allowing them greater status and influence over family economic decisions and more fulfilling work than gender norms would otherwise permit (Seena B. Kohl 1977: 47 - 54; Patricia A. Frishkoff and Bonnie M. Brown 1993: 66 - 70; Lim 1997: 21 - 31; 
Dhaliwal 1998: 463 - 74; Min-Jung Kwak 2002). From this perspective it is possible to view joint family enterprises as positive examples of a more cooperative, less individualistic form of market activity and a means for women to reduce conflict between their market and household responsibilities. At the other pole are those who view unpaid market labor as a means of keeping educated women out of direct labor market competition with men, by giving them a subordinate outlet for their skills and ambition (Hanna Papanek 1973: 852 - 72). In her scathing book about Canadian political wives, for example, journalist Susan Riley argues that such women are ' 'an embarrassment and disgrace to us all ... they embody a patriarchal notion of female virtue which involves trading off personal power for reflected glory', (1987: xiii). These opposing perspectives resonate with the longstanding debate in feminist theory over ' 'sameness' ' versus ' 'difference' ' approaches to gender equality (Nancy Fraser 1997).

Other feminist theorists have focused instead on explaining unpaid market labor as a gendered practice, which supports the moral order underpinning various stages of capitalism. For example, Davidoff and Hall suggest that in the transition to industrial capitalism, women acted as hidden partners in middle-class enterprises, contributing extensively to economic production in ways that were simultaneously consistent with the social rank of having a domestic, ' 'non-working' ' wife (2002: 279 - 87). 
Dorothy Smith focuses on the moral infrastructure of contemporary corporate capitalism, and the crucial role of middle-class wives in signaling the trustworthiness and class status of corporate managers (1975 - 76: 55 90). Her analysis suggests that corporate employers should be viewed as major beneficiaries of women' s unpaid work, along with the individual men whose careers are advanced. Finally, these approaches suggest that unpaid market labor plays an important role in constructing gendered identities. It may also be seen as a marker of heterosexual identity and privilege, though the literature does not discuss this dimension.

Given the diversity of income-generating arrangements within families, it seems overly simplistic to demand that all participants be compensated in money for their work. It would be less controversial, however, to insist upon recognizing the value of unpaid market labor as an input to market production. This approach demands that we assess in a more contextualized fashion how to ensure equitable treatment of individuals who provide unpaid market labor. There is a parallel here to feminist analyses of unpaid domestic labor, many of which call for public policies to take the value and cost of care work into account and encourage equitable sharing of such work but not to commodify it as just another form of wage labor (Lourdes Beneria 1999: 300 - 3; Jean Gardiner 2000: 99 - 100; Susan Himmelweit 2002; Lisa Philipps 2003: 13 - 14). To argue simply that unpaid market 
labor should be eliminated by converting it to paid work risks further reifying the market/family dichotomy as the appropriate frame for public policy and individual subjectivity. Rather than extending the logic of competitive markets further into social life, Jenny Cameron and J. K. Gibson-Graham urge feminists to deconstruct the separation of production and reproduction by studying those spaces within the market that draw upon cooperative behavior (2003: 151 - 5). Research on unpaid market labor can contribute to this deconstructive project by revealing the extent to which families collaborate in work that officially belongs to an individual breadwinner.

This last point raises the question of how unpaid market labor might fit into theories of the care economy. Certainly, it helps to reinforce the argument advanced by feminist economists that markets and households are interdependent aspects of the economy, both necessary for the production of wealth (Diane Elson 1998: 189; Nancy Folbre 2001; Marilyn Power 2004: 6). For example, Elson' s argument that unpaid care work maintains the social framework needed for market relations can be presented even more strongly when unpaid market labor is included in the picture, particularly the role that silent partners play in smoothing commercial relationships. More profoundly, demonstrating why unpaid market labor cannot be located comfortably in either the productive or 
reproductive spheres helps expose the contingency of this boundary and challenge its legitimacy as a basis for allocating resources (David M. Brennan 2006).

Foregrounding family members' direct involvement in breadwinning challenges a central premise of much feminist work in political economy, which posits that industrial capitalism split waged work in the market from unwaged work in the household, replacing an earlier mode in which households functioned as common units of production and economic survival (Antonella Picchio 1992). As a consequence, feminist analyses of unpaid work in Western countries have tended to focus heavily on domestic and caregiving tasks. Some feminist research addresses subsistence production, a category that overlaps with the concept of unpaid market labor used in this paper, but typically it is studied in the context of lessdeveloped, agriculturally based economies (Lourdes Beneria 1982: 131 - 2; 2003: 108 - 16, 134 - 6). Studies of women' s informal work could be expanded to consider the issues discussed in this paper. The informal sector is generally defined to include unpaid family workers but also a wide array of other casual and sometimes illegal activities, usually undertaken to earn cash income and not necessarily embedded in family relations (Beneria 1999: 290 - 1). Recently economists have questioned the traditional view that informal work recedes with industrialization and have begun to 
consider its importance in the flexibilization of labor markets even in developed countries (Martha Chen 2004).

If it can be shown that a wide range of market activities relies systematically upon the provision of unpaid market labor by family members, this suggests that market production has not entirely moved outside households even in Western economies. Thus, Jane Wheelock and Susan Baines concluded that work patterns in micro-businesses in North East England ' 'showed the business family as a production unit,' ' in which survival depended heavily on a flexible supply of family labor both for the business and to address domestic needs (1998: 59). Their study indicates that informal and subsistence labor is crucial to economic development even in the most industrialized settings (Wheelock and Baines 1998: 62; Mark Granovetter 1995: 129 - 30).

All this suggests that taking unpaid market labor seriously may both strengthen and complicate feminist political economy. While work on the care economy has successfully troubled the ideological dichotomization of market and household, it may also paradoxically reinforce it by calling up the family or the household as the site of only domestic (that is, nonmarket) activities. Feminist theory has tended to challenge the production/ reproduction boundary by imagining the household as an underpinning or source of essential inputs to the market, in the form of labor power and 
cooperative social values (Isabella Bakker and Diane Elson 1998: 297; Philipps 2003). This conceptualization demonstrates the close linkages between caregiving and market productivity, but it can still coexist with the notion that paid work itself is an individual undertaking. Studying unpaid market labor has the potential to extend concepts of care beyond the work of nurturing people who then enter markets as autonomous individuals to better reflect the way family members work as a collective to reproduce the family household. In addition to showing the reciprocal flow of goods and services across the market/household boundary, then, highlighting unpaid market labor may go somewhat further to show how these spheres overlap and interweave.

\section{CONCLUSION: A RESEARCH AGENDA}

This paper has identified unpaid market labor as a form of economic activity that cannot be fully understood as a mere subset of unpaid domestic or care work, nor as a form of labor-market participation per se. Rather, I have argued that unpaid market labor deserves its own analysis as a means of deepening feminist critiques of the ideological separation between production and reproduction, market and family. The tax cases from Canadian courts discussed in the first part of this paper illustrate some of 
the ways in which paid workers may draw upon a family member' $\mathrm{s}$ assistance and how Canadian law presently characterizes that assistance dichotomously as either a market or domestic activity. Yet it is difficult to advise on the ' 'correct' ' tax treatment of this form of unpaid labor without confronting the complex theoretical and political questions raised in the paper' s second part. Grappling with these questions will be critical in resolving policy debates, such as the recent one in Canada, over whether to allow couples to split income for tax purposes even where it is legally controlled by one of the partners alone (Frances Woolley 2007; Lisa Philipps 2006; REAL Women of Canada 2006). Conservatives advocating this form of notional income splitting have often cited the value of women' $\mathrm{s}$ unpaid work and may see the contribution of unpaid market labor as further bolstering this argument. Without attempting a full discussion here, a feminist analysis would focus attention on the intrahousehold distribution of resources and power, and whether tax benefits would be better provided directly to those doing unpaid market work, rather than indirectly through a tax reduction for the official breadwinner. It would assess whether income splitting offers differential benefits depending on factors such as class, racial and sexual identity, and family form. It would further evaluate the incentive effects of income splitting, including whether it encourages reliance on unpaid market labor or discourages the 
formalization of employment or partnership relationships within households, and it would evaluate these incentives against different visions of gender equality.

Many other areas of public policy should also be reexamined through the lens of unpaid market labor. For example, how should this form of contribution affect property rights on marriage breakdown or inheritance rights? In corporate law, what protections should be afforded to those who provide unpaid market labor but have no legal status as directors, officers, employees, or shareholders? Do professional estate planners have legal or ethical obligations toward family members who have provided unpaid market labor to their client' s business (Alysa Christmas Rollock 1998: 567)? Corporate recruiters sometimes talk of hiring ' 'two for the price of one,' ' acknowledging that both members of a couple will be involved in performing a job that officially belongs only to one spouse (Kingston 2001: 27). Should such an employer have any responsibilities toward an executive spouse, for example, to provide a salary or a working environment free of harassment and discrimination? Conversely, is there a need to protect those without a female spouse from discrimination by employers who are looking for unpaid market labor that will advance corporate interests?

A host of issues also arise in relation to self-employment. As Wheelock and Baines argue ' 'the entrepreneurial character of the family, not just of 
the individual, needs to be examined' ' (1998: 58). For example, are the lending policies of financial institutions or microcredit organizations fair towards unpaid family members who are involved in a business? Should government self-employment programs include more training and support for those who will assist the ' 'entrepreneur,' ' including advice about their legal status and rights? For example, Binkley (2002) has observed that the income support and retraining programs designed to assist those impacted by the fisheries crisis on the Canadian East Coast were delivered only to licensed fishers, overwhelmingly men. They provided nothing to the wives who had been intimately involved in operating the family fishing business as shore crew or managers, failing to recognize the contributions and the economic losses of unpaid family members (Binkley 2002: 10 - 11). Making these questions visible, and developing answers to them, depends upon generating new theoretical and empirical knowledge about unpaid market labor.

Lisa Philipps, Osgoode Hall Law School, York University, 4700 Keele Street, Toronto, Ontario, M3J 1 P3 Canada e-mail:lphilipps@osgoode.yorku.ca

\section{ACKNOWLEDGMENTS}

The author expresses deep thanks to Jennifer Johnson for superb and timely research assistance as well as many inspiring conversations and insightful comments during the preparation of this paper. The paper has benefited greatly from the suggestions of anonymous reviewers and comments of Janeen Baxter, Kim Brooks, Barbara Cameron, Shelley Gavigan, Freya 
Kodar, Myra Lefkowitz, Meg Luxton, Rod Macdonald, Richard Moon, Mariana Valverde, Leah Vosko, Toni Williams, and students attending the Winter 2004 Osgoode Feminist Discussion Forum. The author gratefully acknowledges the support of the Social Sciences and Humanities Research Council for this research project, and thanks Osgoode Hall Law School for granting her an Osgoode Research Fellowship during the fall term of 2004. Comments are welcome and can be sent to the author.

\section{NOTE}

${ }^{1}$ While the Court cited this definition from the Partnership Act of Manitoba, the definition is very similar in other provinces including Ontario where the Wessells carried on business. 


\section{REFERENCES}

Baines, Susan and Jane Wheelock. 1998. ' 'Reinventing Traditional Solutions: Job Creation, Gender and the Micro-Business Household.' Work, Employment \& Society 12(4): $579-601$.

Bakker, Isabella and Diane Elson. 1998. ' 'Towards Engendering Budgets,' ' in Canadian Centre for Policy Alternatives and Choices: A Coalition for Social Justice (ed.). Alternative Federal Budgets Papers, pp. 297 - 324. Ottawa: Canadian Centre for Policy Alternatives.

Belcourt, Monica, Ronald J. Burke, and Hélène Lee-Gosselin. 1991. The Glass Box: Women Business Owners in Canada. Ottawa: Canadian Advisory Council on the Status of Women.

Beneria, Lourdes. 1982. ' 'Accounting for Women' s Work,' ' in Lourdes Beneria, ed. Women and Development: The Sexual Division of Labor in Rural Societies, pp. 119 - 48. New York: Praeger.

_— 1999. ' 'The Enduring Debate over Unpaid Labour.' ' International Labour Review 138(3): $287-309$.

- - 2003. Gender, Development, and Globalization: Economics as if All People Mattered. London and New York: Routledge.

Binkley, Marian. 2002. Set Adrift: Fishing Families. Toronto: University of Toronto Press.

Boris, Eileen. 1994. Home to Work: Motherhood and the Politics of Industrial Homework in the United States. Cambridge: Cambridge University Press.

Brennan, David M. 2006. ' 'Defending the Indefensible? Culture' s Role in the Productive/Unproductive Dichotomy.' ' Feminist Economics 12(3): 403 - 25.

Callan, Hillary. 1984. ' 'Introduction,' ' in Hillary Callan and Shirley Ardener, eds. The Incorporated Wife. pp. 1 - 26. London: Croom Helm.

Cameron, Jenny and J. K. Gibson-Graham. 2003. 'Feminizing the Economy: Metaphors, Strategies, Politics.' ' Gender, Place and Culture 10(2): 145 - 57.

Chen, Martha. 2004. ' 'Informality at Work: Reconceptualizing the Employment Challenge.' ' Paper presented at the 50th Anniversary Conference Reviewing the First Decade of Development and Democracy in South Africa, University of KwaZulu Natal. Davidoff, Leonore and Catherine Hall. 2002. Family Fortunes: Men and Women of the English Middle Class 1780-1850. Rev. ed. London and New York: Routledge.

Dhaliwal, Spinder. 1998. ' 'Silent Contributors: Asian Female Entrepreneurs and Women in Business.' ' Women's Studies International Forum 21(5): 463 - 74.

Donnelly, Maureen, Joanne Magee, and Allister Young. 2000. ' 'Income Splitting and the New Kiddie Tax: Major Changes for Minor Children.' ' Canadian Tax Journal 48(4): 979 - 1018.

Elson, Diane. 1998. 'The Economic, the Political and the Domestic: Businesses, States and Households in the Organisation of Production.' ' New Political Economy 3(2): 189 208.

Exchequer Court. 1969. Hale v. Canada. 1 Ex.C.R. 259.

- 1970. Philp v. Canada. Ex.C.R. 496.

Federal Court of Appeal. 1996. Lowe v. Her Majesty the Queen. 96 D.T.C. 6226.

Finch, Janet. 1983. Married to the Job: Wives' Incorporation in Men's Work. London: George Allen \& Unwin.

Folbre, Nancy. 2001. The Invisible Heart: Economics and Family Values. New York: The New Press.

Fraser, Nancy. 1997. Justice Interruptus: Critical Reflections on the Postsocialist Condition. New York: Routledge.

Frishkoff, Patricia A. and Bonnie M. Brown. 1993. ' 'Women on the Move in Family Business.' ' Business Horizons 36(2): 66 - 70.

Gardiner, Jean. 2000. 'Domestic Labour Revisited: a Feminist Critique of Marxist 
Economics,' ' in Susan Himmelweit, ed. Inside the Household: From Labour to Care, pp. 80 - 101. Basingstoke: Macmillan; New York: St. Martin' s Press.

Granovetter, Mark. 1995. ' 'The Economic Sociology of Firms and Entrepreneurs,' ' in Alejandro Portes, ed. The Economic Sociology of Immigration: Essays on Networks, Ethnicity, and Entrepreneurship, pp. 128 - 65. New York: Russell Sage Foundation.

Hewitt, Belinda, Mark Western, and Janeen Baxter. 2005. ' Marriage and Money: The Impact of Marriage on Men' s and Women' s Earnings.' ' Australian Journal of Labour Economics 8(2): 163 - 180.

Himmelweit, Susan. 2002. ' 'Making Visible the Hidden Economy: the Case for GenderImpact Analysis of Economic Policy.' ' Feminist Economics 8(1): 49 - 70.

Hughes, Karen D. 1999. Gender and Self-Employment in Canada: Assessing Trends and Policy Implications. Ottawa: Canadian Policy Research Networks.

Kanter, Rosabeth Moss. 1977. Men and Women of the Corporation. New York: Harper Collins.

Kessler-Harris, Alice. 2001. In Pursuit of Equity: Women, Men and the Quest for Economic Citizenship in 20th Century America. Oxford and New York: Oxford University Press.

Kim, Kwang Chung and Won Moo Hurh. 1988. ' 'The Burden of Double Roles: Korean Wives in the USA.' ' Ethnic and Racial Studies 11(2): 151 - 67.

Kingston, Anne. 2001. ' 'What' s A Wife Worth?' ' Saturday Night, May 12.

Kohl, Seena B. 1977. ' 'Women' s Participation in the North American Family Farm.' ' Women's Studies International Quarterly 1(1): 47 - 54.

Kwak, Min-Jung. 2002. Work in Family Businesses and Gender Relations: A Case Study of Recent Korean Immigrant Women. Master' s thesis, York University.

Leach, Peter, Bruce Ball, and Garry Duncan. 2003. Guide to the Family Business. Canadian ed. Scarborough: Thomson Canada Ltd.

Lim, In-Sook. 1997. ' 'Korean Immigrant Women' s Challenge to Gender Inequality at Home: The Interplay of Economic Resources, Gender and Family.' ' Gender and Society 11(1): $21-31$.

Macklin, Audrey. 1992. ' 'Symes v. M.N.R.: Where Sex Meets Class.' ' Canadian Journal of Women and the Law 5(1): 498 - 517.

Morris, Betsy. 1998. ' 'It' s Her Job Too.' ' Fortune 137(2): 64.

Papanek, Hanna. 1973. 'Men, Women and Work: Reflections on the Two-Person Career.' ' American Journal of Sociology 78(4): 852 - 72.

Philipps, Lisa. 2002. " 'Tax Law and Social Reproduction: The Gender of Fiscal Policy in an Age of Privatization,' ' in Brenda Cossman and Judy Fudge, eds. Privatization, Law and the Challenge to Feminism, pp. 41 - 85. Toronto: University of Toronto Press.

- - 2003. ' 'There' s Only One Worker: Toward the Legal Integration of Paid Employment and Unpaid Caregiving,' ' in Law Commission of Canada, ed. New Perspectives on the Public-Private Divide, pp. 3 - 39. Vancouver and Toronto: UBC Press.

——. 2006. Income Splitting: Who Really Benefits? http://www.cbc.ca/news/ viewpoint/vp_philipps/20061122.html (accessed November 2007).

Phillips, Paul and Erin Phillips. 1993. Women \& Work: Inequality in the Canadian Labour Market. Toronto: James Lorimer \& Co.

Phipps, Shelley and Frances Woolley. 2006. 'Control Over Money and Wealth Accumulation in Canadian Families.' ' Carleton Economic Papers 06-02. http:// www.carleton.ca/economics/cep/cep06-02.pdf (accessed November 2007).

Picchio, Antonella. 1992. Social Reproduction: The Political Economy of the Labour Market. Cambridge: Cambridge University Press.

Pinchbeck, Ivy. 1969. Women Workers and the Industrial Revolution, 1750-1850. 1st ed. New York: A.M. Kelley.

Power, Marilyn. 2004. ' ' 'Social Provisioning as a Starting Point for Feminist Economics.' ' Feminist Economics 10(3): 3 - 19.

REAL Women of Canada. 2006. ' 'Financial Help Granted to Seniors - Pension Splitting.' REALity XXV(6). http://www.realwomenca.com/newsletter/2006_nov_dec/arti- cle_2.html 
(accessed April 2007).

Rhodes, Linda. 2003. ' 'Partners on the Periphery: Personal Ambiguity and Unpaid Labour in the Australian Mining Industry.' ' Journal of Australian Studies (76): 149 - 58.

Riley, Susan. 1987. Political Wives: The Lives of the Saints. Toronto: Deneua.

Rollock, Alysa Christmas. 1998. ' 'Professional Responsibility and the Organization of the Family Business: The Lawyer as Intermediary.' ' Indiana Law Journal 73(2): 567 - 87.

Rowe, Barbara R. and Gong-Soog Hong. 2000. ' 'The Role of Wives in Family Businesses: The Paid and Unpaid Work of Women.' ' Family Business Review 13(1): 1 - 13.

Sirianni, Carmen and Cynthia Negrey. 2000. ' 'Working Time as Gendered Time.' Feminist Economics 6(1): 59 - 76.

Smith, Dorothy. 1975. ' 'Women, the Family and Corporate Capitalism.' ' Berkeley Journal of Sociology 20: 55 - 90.

Staudt, Nancy C. 1996. "The Political Economy of Taxation: A Critical Review of a Classic.' ' Law and Society Review 30(3): 651 - 66.

Supreme Court of Canada. 1994. Symes v. The Queen. 94 D.T.C. 6001.

Tax Appeal Board. 1966. Shambrook v. Minister of National Revenue. 66 D.T.C. 20.

- - 1968. Paton v. Minister of National Revenue. 68 D.T.C. 197.

Tax Court of Canada. 1985a. Cullen vs. Canada. 85 D.T.C. 409.

- 1985 b. Wessell vs. Canada. 85 D.T.C. 206.

- 1993. McMillan vs. Canada. T.C.J. No. 296.

UK Inland Revenue. Undated. A Guide to the Settlements Legislation for Small Business Advisors, http://www.hmrc.gov.uk/practitioners/guide_sba.pdf (accessed August 2005).

Walby, Sylvia. 2000. 'The Restructuring of the Gendered Political Economy: Transformations in Women' s Employment,' in Joanne Cook, Jennifer Roberts, and Georgina Waylen, eds. Towards a Gendered Political Economy, pp. 165 - 97. Houndmills, Basingstoke, and Hampshire, Great Britain: Macmillan Press Ltd.

Walton-Roberts, Margaret and Daniel Hiebert. 1997. ' 'Immigration, Entrepreneurship, and the Family: Indo-Canadian Enterprise in the Construction Industry of Greater Vancouver.' ' Canadian Journal of Regional Science 20(1-2): 1 - 18.

Wheelock, Jane. 1992. ' 'The Flexibility of Small Business Family Work Strategies,' ' in Kevin Caley, Elizabeth Chell, Francis Chittenden, and Colin Mason, eds. Small Enterprise Development: Policy and Practice in Action, pp. 151 - 65. London: UK Enterprise Management and Research Association.

Wheelock, Jane and Susan Baines. 1998. ' 'Dependency or Self-Reliance? The Contra- dictory Case of Work in UK Small Business Families.' ' Journal of Family and Economic Issues 19(1): $53-73$.

Williams, Joan. 2000. Unbending Gender: Why Family and Work Conflict and What To Do About It. New York: Oxford University Press.

Woolley, Frances. 2007. 'Liability Without Control: The Curious Case of Pension Income Splitting.' ' Carleton Economic Papers 07-06. http://www.carleton.ca/economics/ cep/cep07-06.pdf (accessed November 2007). 